\title{
Analisis Karakteristik Serbuk Sabut Kelapa (Cocopeat) Sebagai Agregat Halus pada Campuran Beton
}

\author{
Hezliana Syahwanti ${ }^{1 *}$, Irvhaneil ${ }^{2}$, Ranty Christiana ${ }^{3}$ \\ 1,2,3 Program Studi Teknik Sipil, Fakultas Teknik, Universitas Panca Bhakti, Pontianak \\ *Koresponden email: hezliana.syahwanti@upb.ac.id
}

Diterima: 5 November 2021

Disetujui: 17 Desember 2021

\begin{abstract}
The advantages of coconut coir powder (cocopeat) are resistant to microorganisms, weathering and resistant to mechanical spelling, namely friction and blows. Based on these advantages, cocopeat can be used as a blend of fine aggregates in the manufacture of concrete. The sieve test was conducted on the cocopeat to determine the initial feasibility analysis of cocopeat as a blend of fine aggregates in the concrete manufacturing. The results of the cocopeat sieve test are that cocopeat is included in Region II which is classified as a fine module of slightly coarse grains with a fine module of fine aggregate grains of 2.37. This shows that cocopeat has a fairly good value in normal concrete mixtures but is not suitable for high resistance concrete mixtures that exceed $25 \mathrm{MPa}$. This was followed by a subsidence test that gave subsidence values for mixtures of concrete with a cocopeat composition of $25 \%, 50 \%$ and $75 \%$, is $7.5 \mathrm{~cm}$; $5.3 \mathrm{~cm}$; and $2.2 \mathrm{~cm}$. While a good subsidence ratio is used in the range of $6-18 \mathrm{~cm}$. In addition, the concrete with a $25 \%$ blend of cocopeat has a stronger physical form and there are no fungus growing on the surface of the concrete. Meanwhile, concrete with a mixture of $50 \%$ and $75 \%$ cocopeat looks more fragile and forms molds on the surface of the concrete. Thus the concrete with a mixture of $25 \%$ cocopeat has better results.
\end{abstract}

Keywords: Concrete, Cocopeat, Slump Grade, Concrete Mixture, Fine Aggregate

\begin{abstract}
Abstrak
Keunggulan serbuk sabut kelapa (cocopeat) yaitu tahan terhadap mikroorganisme, pelapukan dan tahan terhadap pengejaan mekanis yaitu gesekan dan pukulan. Berdasarkan keunggulan tersebut maka cocopeat dapat dijadikan salah satu bahan campuran agregat halus dalam pembuatan beton. Uji saringan dilakukan pada cocopeat untuk mengetahui analisis awal kelayakan cocopeat sebagai bahan campuran agregat halus pada pembuatan beton. Hasil uji saringan cocopeat yaitu cocopeat termasuk ke dalam Daerah II yang tergolong modulus halus butir berjenis agak kasar dengan nillai modulus halus butir agregat halus sebesar 2.37. Hal ini menunjukkan bahwa cocopeat memiliki nilai yang cukup baik pada campuran beton normal tetapi tidak cocok untuk campuran beton mutu tinggi yang melebihi dari $25 \mathrm{Mpa}$. Selanjutnya dengan uji slump yang menghasilkan nilai slump untuk campuran beton dengan komposisi cocopeat 25\%, 50\% dan $75 \%$ yaitu $7,5 \mathrm{~cm} ; 5,3 \mathrm{~cm}$; dan 2,2 cm. Sedangkan nilai slump yang baik digunakan yaitu pada rentang $6-$ $18 \mathrm{~cm}$. Selain itu, beton dengan campuran cocopeat sebesar $25 \%$ memiliki bentuk fisik yang lebih kokoh dan tidak ada tumbuh jamur pada permukaan beton. Sedangkan beton dengan campuran cocopeat $50 \%$ dan $75 \%$ terlihat lebih rapuh dan terbentuk jamur pada permukaan beton sehingga beton dengan campuran cocopeat $25 \%$ memiliki hasil yang lebih baik.
\end{abstract}

Kata Kunci: beton, cocopeat, nilai slump, campuran beton, agregat halus

\section{Pendahuluan}

Badan Pusat Statistik Provinsi Kalimantan Barat mencatat produksi perkebunan rakyat untuk jenis perkebunan kelapa dalam memiliki peningkatan dari tahun 2015 hingga tahun 2019. Pada Tahun 2015 tercatat sebanyak 75.973 kelapa yang diproduksi di Kalimantan Barat, sedangkan pada Tahun 2019 mengalami peningkatan yaitu sebanyak 81.301 kelapa yang diproduksi di Kalimantan Barat [1]. Kelapa memiliki limbah berupa sabut kelapa, dimana serabut ini merupakan bagian yang cukup besar dari buah kelapa yaitu sekitar 35\% dari berat keseluruhan buah kelapa [2]. Sampai saat ini limbah sabut kelapa masih terbatas pemanfaatannya, yaitu hanya dibidang industri-industri mebel, kerajinan rumah tangga, dan di bidang pertanian.

Sabut kelapa yang dimanfaatkan akan melalui proses penghacuran terlebih dahulu dimana hasil dari proses ini yaitu berupa serat kelapa (cocofiber) dan serbuk halus kelapa (cocopeat) [3]. Pemanfaatan serat kelapa (cocofiber) sudah dilakukan diberbagai bidang salah satunya dibidang Teknik Sipil yaitu dalam 
$\overline{\text { pembuatan beton. Hasilnya terdapat kenaikan pada kuat tekan beton sebesar } 9 \% \text { pada bahan pembuatan }}$ beton dengan tambahan serat sabut kelapa [4]. Sedangkan untuk pemanfaatan serbuk halus kelapa (cocopeat) sampai saat ini masih terbatas salah satu hanya dimanfaatkan dibidang pertanian saja.

Bentuk fisik cocopeat berupa butiran halus seperti pasir dan menyerupai tanah [5]. Kemiripan bentuk fisik ini dapat menjadi landasan awal potensi cocopeat sebagai bahan campuran agregat halus dalam pembuatan beton. Beton sendiri terbentuk dari pengerasan semen, kerikil, pasir, dan air. Sebelum melakukan pencampuran bahan pembuatan beton akan dilakukan pengujian bahan terlebih dahalu. Seperti halnya di campuran agregat halus yang berupa pasir harus dilakukan analisis uji saringan terlebih dahulu untuk mengetahui kualitas pasir yang digunakan. Berdasarkan hal tersebut maka analisis uji saringan juga dapat dilakukan pada cocopeat untuk mengetahui kelayakan cocopeat sebagai agregat halus dalam campuran beton. Tujuan penelitian ini adalah mengetahui karakteristik cocopeat sebagai campuran agregat halus dalam pembuatan beton untuk meningkatkan daya tahan beton dibandingkan dengan beton konvensional.

\section{Bahan dan Metode Alat dan Bahan}

Alat yang digunakan dalam penelitian ini adalah cetakan beton silinder, bak perendam, skop, corong atau kerucur abrams, timbangan, sendok semen, saringan ukuran lubang ayakan $2.36 \mathrm{~mm}, 1.18 \mathrm{~mm}, 0.5$ $\mathrm{mm}, 0.212 \mathrm{~mm}, 0.150 \mathrm{~mm}$ dan $0.075 \mathrm{~mm}$, mesin pengguncang atau penggetar saringan dan oven. Bahanbahan yang digunakan dalam penelitian ini adalah serbuk sabut kelapa (cocopeat), semen portland, kerikil, pasir dan air.

\section{Metode Penelitian}

Penelitian ini dilakukan dengan pengujian bahan dasar pembuatan campuran beton. Pada dasarnya dalam pembuatan beton menggunakan agregat halus dan agregat kasar. Uji saringan dilakukan pada agregat halus yaitu cocopeat dan pasir. Sedangkan untuk agregat kasar, ukuran kerikil yang digunakan yaitu dibawah $20 \mathrm{~mm}$. Uji saringan dilakukan pada bahan cocopeat dengan ukuran ayakan $2.36 \mathrm{~mm}, 1.18 \mathrm{~mm}$, $0.5 \mathrm{~mm}, 0.212 \mathrm{~mm}, 0.150 \mathrm{~mm}$, dan $0.075 \mathrm{~mm}$ yang selanjutnya akan dianalisis daerah jenis butiran dari cocopeat tersebut. Uji saringan juga akan dilakukan pada pasir dengan perlakuan yang sedikit berbeda dari cocopeat. Pada cocopeat tidak dilakukan pengovenan sedangkan pada pasir akan dilakukan pengovenan terlebih dahulu sebelum diayak dengan saringan.

Setelah itu campuran beton akan dibuat dengan melakukan variasi pada campuran agregat halus sebagai berikut:

1. Campuran 1 : Kandungan cocopeat $25 \%$ dan kandungan pasir $75 \%$ dari berat keseluruhan yaitu $661 \mathrm{~kg} / \mathrm{m}^{3}$

2. Campuran 2 : Kandungan cocopeat $50 \%$ dan kandungan pasir $50 \%$ dari berat keseluruhan yaitu $661 \mathrm{~kg} / \mathrm{m}^{3}$

3. Campuran 3 : Kandungan cocopeat $75 \%$ dan kandungan pasir $25 \%$ dari berat keseluruhan yaitu $661 \mathrm{~kg} / \mathrm{m}^{3}$

Selanjutnya semen, agregat halus, agregat kasar, dan air diaduk menjadi satu adonan yang kemudian setelah menyatu akan dilakukan slump test yaitu pengujian kekentalan adonan beton. Nilai slump test yang digunakan dalam penelitian ini yaitu $60 \mathrm{~mm}$ hingga $180 \mathrm{~mm}$. Kemudian adonan dimasukkan ke dalam cetakan beton berbentuk silinder ukuran diameter $15 \mathrm{~cm}$ dan tinggi $30 \mathrm{~cm}$. Selanjutnya akan dilakukan pencampuran bahan dalam pembuatan beton sesuai dengan SNI 2847-2013[6]. Secara keseluruhan metode penelitian [7]dapat dilihat pada Gambar 1. 


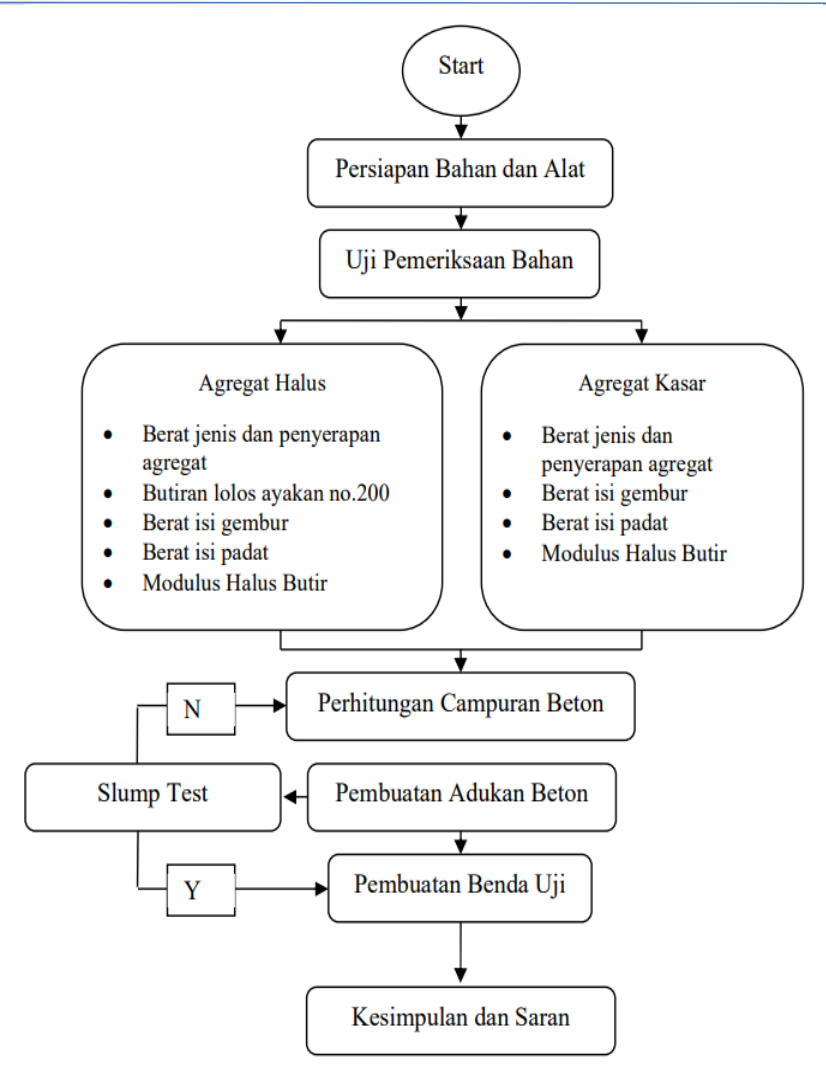

Gambar 1. Alur Penelitian

Sumber: Riset (2021)

\section{Serbuk Sabut Kelapa (Cocopeat)}

Cocopeat atau serbuk sabut kelapa merupakan serbuk halus dari sabut kelapa yang dihasilkan dengan proses penghancuran sabut kelapa. Cocopeat memiliki sifat dapat menahan kandungan air dan beberapa unsur kimia lainnya [8]. Serbuk sabuk kelapa (cocopeat) memiliki bentuk fisik yang mirip dengan pasir. Cocopeat memiliki bentuk berupa butiran halus yang memiliki kelebihan dikarenakan karakteristiknya yang mampu menyimpan air dengan kuat dan memiliki $\mathrm{pH}$ yang hampir sama dengan tanah [9]. Bentuk fisik cocopeat yang mirip dengan pasir dapat menjadikannya sebagai salah satu bahan tambahan agregat halus dalam pembuatan beton. Agregat halus yang digunakan dalam pembuatan beton harus memenuhi syarat sebagai berikut [10]:

1. Butiran halus yang tajam dan keras

2. Butirannya harus bersifat kekal

3. Tidak boleh mengandung lumpur lebih dari $5 \%$ berat keringnya

4. Tidak boleh mengandung bahan organik terlalu banyak

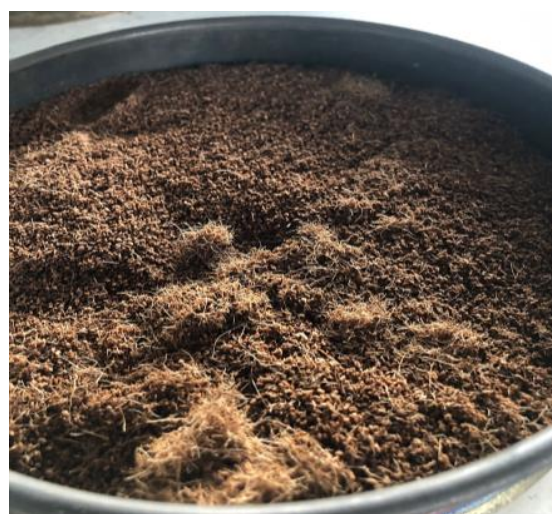

Gambar 2. Cocopeat

Sumber: Riset (2021) 


\section{Hasil dan Pembahasan}

Beberapa keunggulan serbuk sabut kelapa (cocopeat) yaitu tahan terhadap mikroorganisme, pelapukan dan tahan terhadap pengejaan mekanis yaitu gesekan dan pukulan. Berdasarkan keunggulan tersebut maka cocopeat dapat dijadikan salah satu bahan campuran agregat halus dalam pembuatan beton. Uji saringan dilakukan pada cocopeat untuk mengetahui analisis awal kelayakan cocopeat sebagai bahan campuran agregat halus pada pembuatan beton. Hasil analisa saringan terhadap cocopeat ini jika mengacu pada kedalam grafik daerah gradasi pasir, maka dapat ditentukan bahwa cocopeat yang diperiksa masuk kedalam Daerah II yang tergolong modulus halus butir berjenis agak kasar yang terlihat dari Gambar 3. Hasil pemeriksaan menunjukkan nilai modulus halus butir agregat halus sebesar 2.37, hal ini mengindikasikan bahwa bahan cocopeat yang akan digunakan dalam campuran beton cukup baik pada campuran beton normal tetapi tidak baik untuk campuran beton mutu tinggi yang melebihi dari $25 \mathrm{Mpa}[11]$.

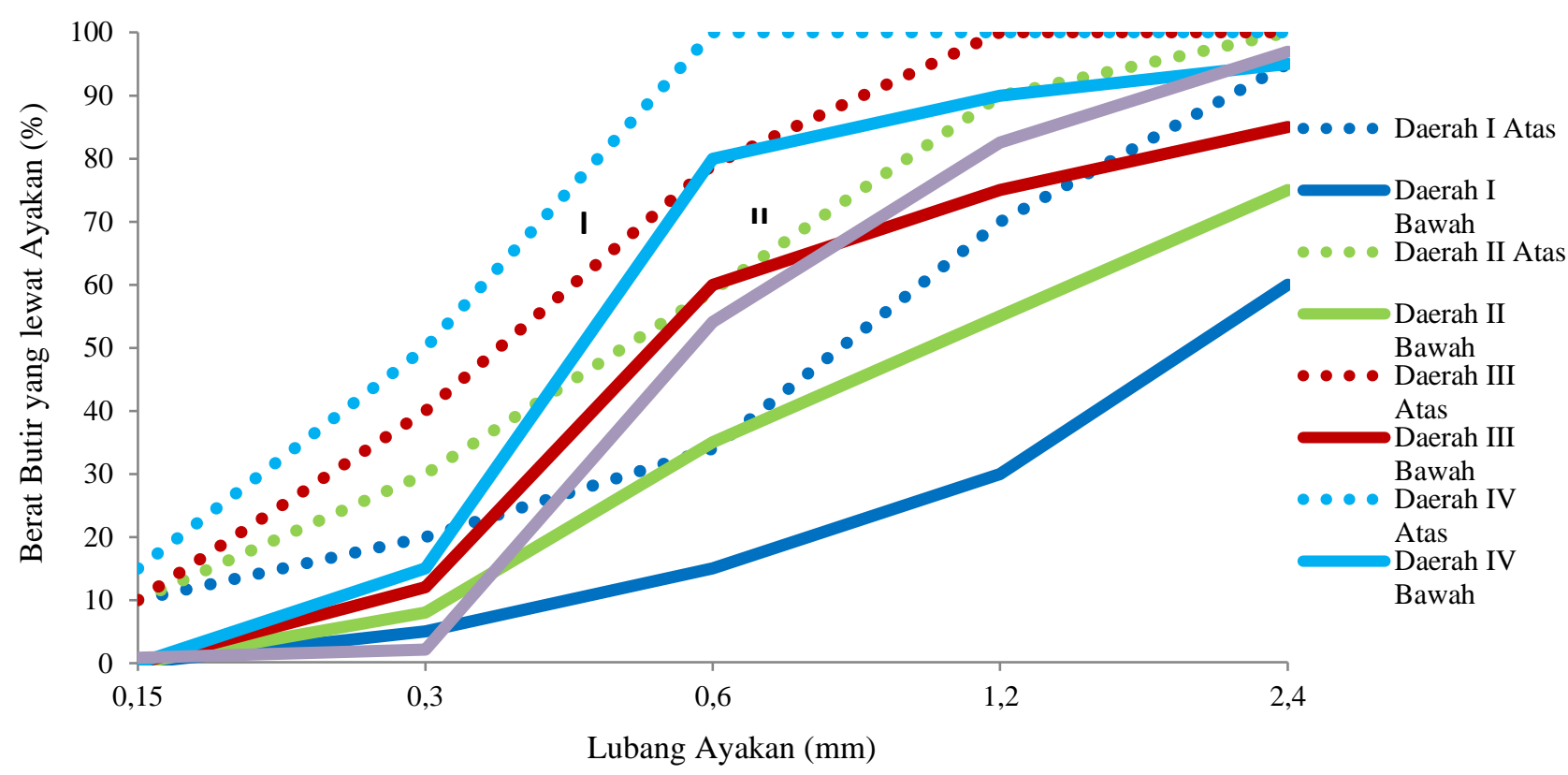

Gambar 3. Grafik Gradasi Cocopeat Sumber: Riset (2021)

Nilai butiran cocopeat yang termasuk ke dalam Daerah II yaitu daerah pasir agak kasar menunjukkan bahwa cocopeat memiliki bentuk yg sedikit besar. Jika dijadikan sebagai agregat halus masih layak tetapi karena ukuran yang agak besar maka cocopeat tidak bisa dengan sempurna memasuki pori-pori kerikil sebagai agregat kasar. Sehingga dapat mempengaruhi kualitas kekuatan beton yang terbentuk. Karena agregat yang agak kasar ini kurang dapat menjadi pengisi yang sempurna pada pori-pori kerikil sehingga terbentuk beton dengan kualitas kurang baik. Selanjutnya untuk mengetahui kualitas cocopeat sebagai bahan campuran beton, dilakukan uji slump sesuai SNI 03-2847-2002 [12].

Pengujian slump atau uji slump dilakukan dengan menggunakan alat bantu berupa kerucut Abrams. Uji ini dilakukan untuk mengetahui tingkat workabilitas (kemudahan dalam pengerjaan) campuran beton yang telah dibuat. Pertama adalah dengan membasahi bagian dalam tabung kerucut Abrams menggunakan air dan kemudian diletakkan diatas plat baja yang memiliki permukaan datar. Kemudian campuran beton yang telah jadi dimasukkan kedalam tabung kerucut dan setiap $1 / 3$ volumenya ditusuk-tusuk sebanyak 25 kali dengan penumbuk baja hingga isi kerucut Abrams penuh. Kemudian beton diratakan permukaannya dan didiamkan selama $1 \frac{1}{2}$ menit, selanjutnya corong kerucut diangkat secara perlahan ke atas tanpa ada gaya horizontal. Pengukuran nilai slump dilakukan dari bagian tertinggi campuran beton sampai ujung atas kerucut Abrams. Nilai yang didapat merupakan nilai slump yang digunakan dalam penentuan kualitas campuran beton yang diuji.

Pada penelitian ini, nilai slump yang digunakan untuk beton mutu normal adalah sebesar $15,5 \mathrm{~cm}$, namun untuk beton dengan campuran cocopeat ini didapat nilai slump yang yaitu sebesar $7,5 \mathrm{~cm}$ pada campuran $25 \%$ cocopeat, $5,3 \mathrm{~cm}$ pada campuran $50 \%$ cocopeat $2,2 \mathrm{~cm}$ campuran $75 \%$ cocopeat. Kecilnya nilai slump dikhawatirkan akan membuat proses pemadatan campuran beton ke dalam cetakan silinder akan 
mengalami kesulitan akibat beton yang bersifat terlalu getas karena faktor air semen yang sangat rendah. Hasil nilai uji slump dalam bentuk grafik dapat dilihat pada Gambar 4.

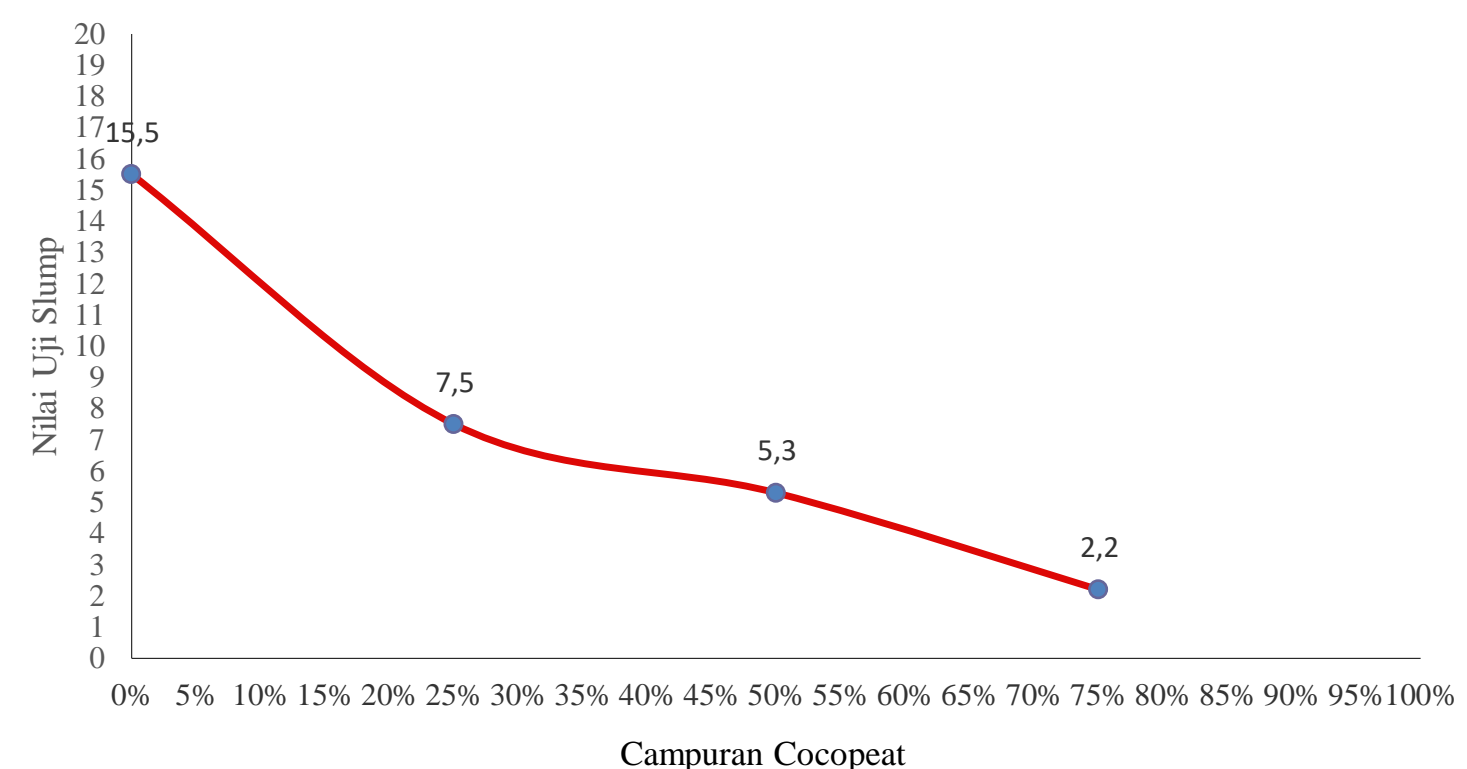

Gambar 4. Grafik slump cocopeat

Sumber: Riset (2021)

Nilai slump yang kecil terbentuk karena cocopeat memiliki sifat penyerapan air yang tinggi. Cocopeat mempunyai kadar air dan daya simpan air masing-masing yaitu 119\% dan 695,4\% [13]. Pada cocopeat yang digunakan dalam penelitian ini didapat nilai kadar air rata-rata 38,95\%. Nilai kadar air yang cukup tinggi ini menunjukkan cocopeat dapat menyerap air dalam jumlah banyak saat dilakukan pencampuran bahan untuk pembuatan beton. Ini dibuktikan dengan nilai slump yang semakin kecil Ketika komposisi cocopeat bertambah dalam campuran beton tersebut.

Pada saat campuran beton yang mengandung cocopeat di masukkan ke dalam cetakan, ternyata kandungan cocopeat tersebut memberi pengaruh yaitu bekas karat yang terbentuk pada cetakan beton. Berdasarkan hasil penelitian dilakukan, saat campuran beton dengan kandungan cocopeat $25 \%$ terbentuk sedikit karatan pada dinding cetakan beton. Saat kandungan cocopeat pada campuran beton ditingkatkan menjadi 50\% terlihat karatan yang menempel pada cetakan beton lebih banyak dari kandungan cocopeat 25\%. Kemudian karatan terbanyak terbentuk di cetakan beton pada campuran beton dengan komposisi $75 \%$ kandungan cocopeat. Pembentukan karatan disetiap kandungan cocopeat dapat dilihat pada Gambar 5, Gambar 6, dan Gambar 7.
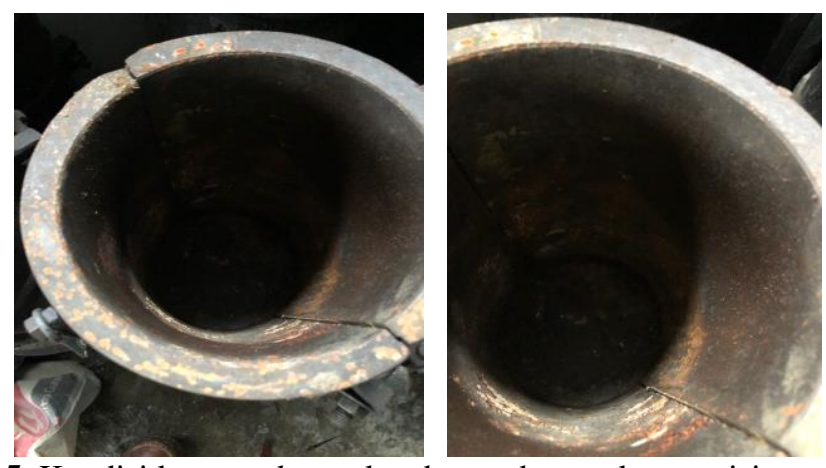

Gambar 5. Kondisi karat pada cetakan beton dengan komposisi cocopeat $25 \%$ Sumber: Riset (2021) 


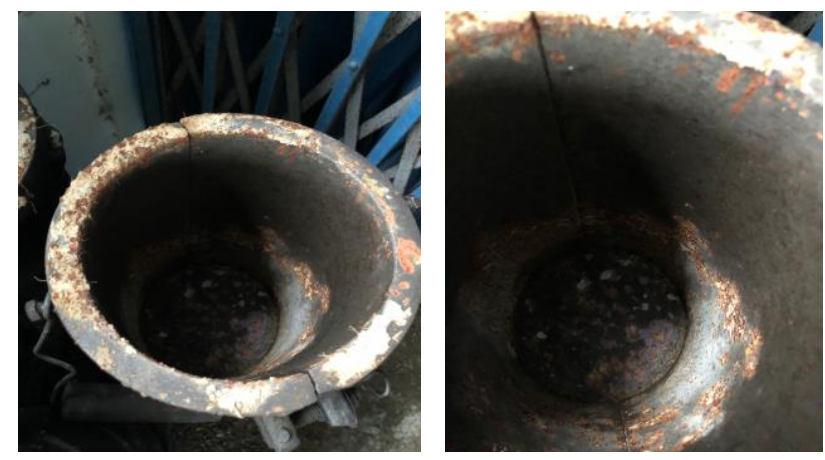

Gambar 6. Kondisi karat pada cetakan beton dengan komposisi cocopeat $50 \%$ Sumber: Riset (2021)

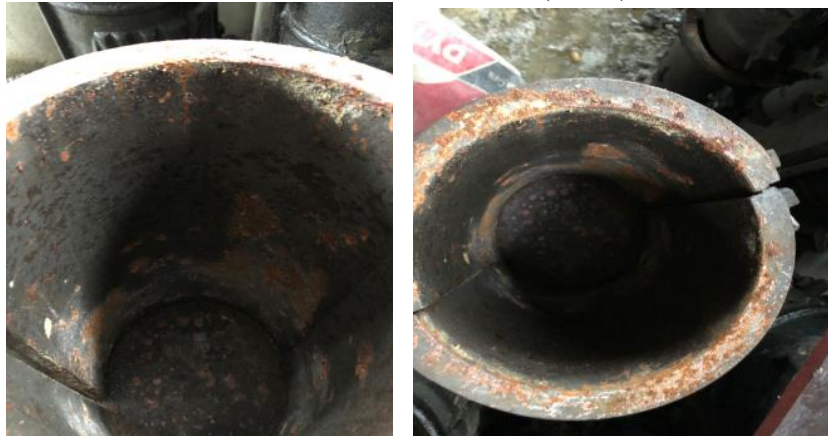

Gambar 7. Kondisi karat pada cetakan beton dengan komposisi cocopeat 75\% Sumber: Riset (2021)

Karatan yang terbentuk bisa diakibatkan oleh kandungan senyawa asam pada bahan yang digunakan. Cocopeat memiliki klor yang cukup tinggi sehingga jika klor tersebut bereaksi dengan air maka akan terbentuk senyawa asam klorida [14]. Karena cocopeat dimasukkan ke dalam adonan beton dimana adonan beton terdiri dari air, semen, pasir dan kerikil maka ketika cocopeat berada dalam campuran adonan tersebut maka kandungan klor berubah menjadi senyawa asam klorida yang membuat kondisi campuran tersebut menjadi asam [15]. Senyawa ini yang membuat karatan terbentuk pada cetakan beton saat adonan beton dimasukkan ke cetakan dan didiamkan beberapa hari hingga beton mengeras. Terbukti semakin banyak kandungan cocopeat yang ditambahkan dalam campuran beton maka semakin banyak juga karatan yang terbentuk pada cetakan beton tersebut. Hasil analisis cocopeat sebagai campuran agregat halus dalam pembuatan beton dapat diihat pada Tabel 1.

Tabel 1. Hasil analisis produk beton dengan campuran cocopeat

\begin{tabular}{cll}
\hline Komposisi & Bentuk dan ukuran & Sifat tampak \\
\hline \multirow{2}{*}{$25 \%$} & $\begin{array}{l}\text { Ketika dikeluarkan dari cetakkan benda uji masih } \\
\text { utuh dan sempurna }\end{array}$ & $\begin{array}{l}\text { Tidak munculnya jamur pada cetakkan benda } \\
\text { uji }\end{array}$ \\
$\begin{array}{l}\text { Ketika dikeluarkan dari cetakkan benda uji masih } \\
\text { utuh dan sempurna }\end{array}$ & $\begin{array}{l}\text { Pada umur 19 hari mulai banyak jamur yang } \\
\text { tumbuh pada silinder benda uji dan terjadi } \\
\text { karatan pada cetakkan benda uji }\end{array}$ \\
& $\begin{array}{l}\text { Mulai terjadi keropos terhadap ikatan antar agregat, } \\
\text { sehingga untuk membawa sampel haruslah hati2 }\end{array}$ & $\begin{array}{l}\text { Berat benda uji sangat ringan, pada umur 19 } \\
\text { silinder benda uji dan terjadi karatan pada } \\
\text { cetakkan benda uji }\end{array}$ \\
\hline
\end{tabular}

Sumber: Riset (2021)

Berdasarkan hasil analisis fisik pada Tabel 1 terlihat bahwa jamur terbentuk pada beton dengan campuran cocopeat 50\% dan $75 \%$. Terbentuknya jamur ini dapat menunjukkan bahwa kualitas beton yang dibuat kurang baik. Sehingga tidak disarankan untuk dilanjutkan dalam proses pembuatan beton dalam jumlah banyak. Pada beton dengan campuran cocopeat $25 \%$ terlihat bentuk beton yang lebih sempurna dan kokoh. Tidak ada jamur yang terbentuk pada beton dengan campuran cocopeat $25 \%$ sehingga beton dengan komposisi ini dapat digunakan dalam proses pembuatan beton untuk jumlah yang banyak. 


\section{Kesimpulan}

Penelitian cocopeat sebagai campuran agregat halus pada pembuatan beton memiliki kesimpulan yaitu cocopeat dapat digunakan sebagai campuran agregat halus bersama pasir. Butiran cocopeat termasuk kedalam Daerah II yaitu jenis pasir yang agak kasar. Sehingga bentuk yang agak kasar ini membuat cocopeat tidak bisa dengan sempurna mengisi seluruh pori-pori kerikil sebagai agregat kasar saat pembuatan campuran beton. Cocopeat juga memiliki sifat penyerapan air yang cukup tinggi, nilai kadar air cocopeat pada penelitian ini adalah $38,95 \%$. Ini mempengaruhi nilai pada pengujian slump. Terbukti saat uji slump untuk kadar cocopeat 25\%; 50\% dan 75\% nilai slump yang terbentuk adalah 7,5 cm; 5,5 cm dan $2,2 \mathrm{~cm}$. Semakin kecil nilai slump maka semakin besar daya serap campuran beton tersebut terhadap air. Selain itu cocopeat juga mengandung klor sehingga ketika bereaksi dengan air terbentuk senyawa asam yang membuat campuran beton dengan tambahan cocopeat menjadi asam dan mengakibatkan terbentuknya karatan pada cetakan beton. Pada hasil analisis fisik beton dengan campuran cocopeat $25 \%$ terlihat lebih kuat dan kokoh karena bentuk yang sempuran dan tidak adanya jamur pada beton tersebut membuat hasil beton dengan kandungan cocopeat $25 \%$ lebih baik dibandingkan beton dengan kandungan cocopeat $50 \%$ dan $75 \%$.

\section{Ucapan Terima Kasih}

Peneliti mengucapkan banyak terima kasih kepada Kementerian Pendidikan, Kebudayaan, Teknologi dan Riset yang telah memberikan dana penuh dalam penelitian ini pada Program Hibah Penelitian Dikti Tahun Anggaran 2021 dan terima kasih juga diberikan kepada Universitas Panca Bhakti Pontianak sebagai tempat dalam melakukan penelitian.

\section{Daftar Pustaka}

[1] Badan Pusat Statistik, Produksi Perkebunan Rakyat, Provinsi Kalimantan Barat, 2019.

[2] T. Indahyani, "Pemanfaatan limbah sabut kelapa pada perencanaan interior dan furniture yang berdampak pada pemberdayaan masyarakat miskin," J. Humaniora, Vol. 2 No.1 Hal 15-23, 2011.

[3] A. Irawan dan H. N. Hidayah, "Kesesuaian penggunaan cocopeat sebagai media sapih pada politube dalam pembibitan cempaka (Magnolia elegans)," J. Wasian, Vol. 1 No. 2 Hal. 73-76, 2014.

[4] E. Prahara, G. T. Liong, dan Rachmansyah, "Analisa pengaruh penggunaan serat serabut kelapa dalam presentase tertentu pada beton mutu tinggi," J. ComTech, Vol. 6 No. 2 Hal. 208-214, 2015.

[5] Dinas Ketahanan Pangan, Cocopeat Sebagai Media Tanam, Provinsi NTB, 2020.

[6] SNI 2847-2013 Persyaratan Beton Struktural Untuk Bangunan Gedung, Badan Standarisasi Nasional, Jakarta, 2013.

[7] Tjokrodimulyo, Kardiyono, "Teknologi Beton", Buku Ajar Jurusan Teknik Sipil Fakultas Teknik UGM, Yogyakarta, 1992.

[8] L. K. Supraptiningsih dan S. Hattarina, "PKM kelompok industri pengolahan limbah sabut kelapa (Cocopeat) Di Kabupaten dan Kota Probolinggo Provinsi Jawa Timur," PEDULI - J. Ilmiah Pengabdian Pada Masyarakat, Vol. 2, No. 2, 2018.

[9] Ramadhan, Dimas, "Pemanfaatan cocopeat sebagai media tumbuh Sengon Laut (Paraserianthes falcataria) dan Merbau Darat (Intsia palembanica)," J. Sylva Lestari, Vol. 6 No.2 Hal. 22-31, 2018.

[10] T. Wahyudi, B. Edison, dan A. Ariyanto, "Penggunaan ijuk dan sabut kelapa terhadap kuat tekan pada beton K-100,” J. Mahasiswa Teknik, Vol. 1 No.1 Tahun 2013, Published 2014-11-05, 2014.

[11] Larrard, De, "A Method for Proportioning High-Strength Concrete Mixture, Cement, Concrete and Agregat", ASTM Vol. 12, Issue 1 pp.46-52, 1990.

[12] SNI 03-2847-2002 Tata Cara Perhitungan Beton Struktur Untuk Bangunan, Badan Standarisasi Nasiona, Jakarta, 2002.

[13] B. Risnawati, "Pengaruh penambahan serbuk sabut kelapa (Cocopeat) pada media arang sekam terhadap pertumbuhan tanaman Sawi Hijau (Brassica juncea L.) secara hidroponik," Skripsi, Universitas Islam Negeri Alauddin Makasar, 2016.

[14] Hasriani, D.K. Kalsim dan A. Sukendro, "Kajian serbuk sabut kelapa (Cocopeat) sebagai media tanam," Respitory IPB: http://repository.ipb.ac.id/handle/123456789/66060, 2013.

[15] Lanjarwati, R., "Pengaruh Macam Media Tanam Terhadap Pertumbuhan dan Hasil Varietas Tomat (Lycopersion esculentum Mill.) Secara Hidroponik Dengan Media Subtrat", Skripsi, Universitas Jember, 2018. 